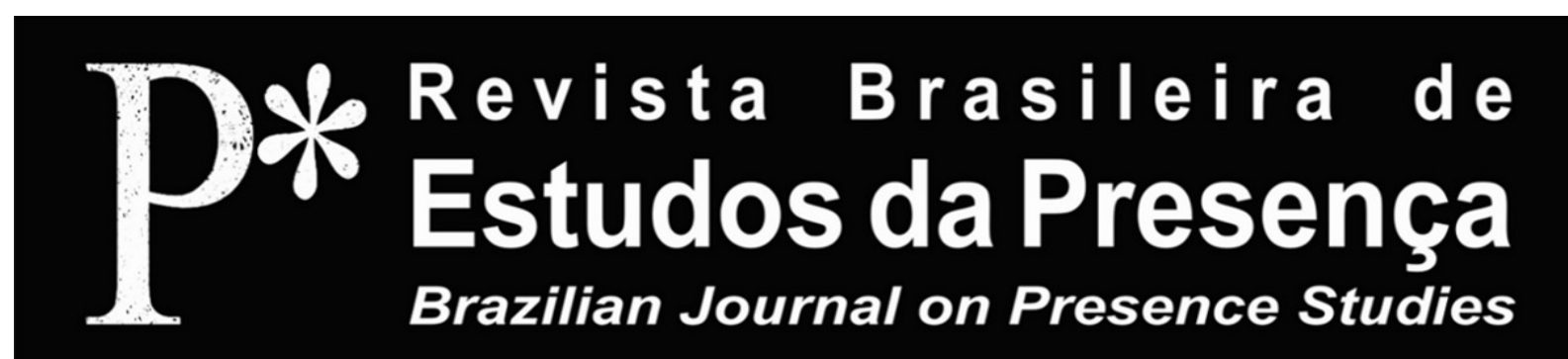

DOI - http://dx.doi.org/10.1590/2237-266045468

ISSN 2237-2660

\title{
Gordon Craig's Self-Contradictions
}

\author{
Patrick Le Boeuf \\ Bibliothèque Nationale de France - BNF, Paris, France
}

\begin{abstract}
Gordon Craig's Self-Contradictions - The seeming contradictions in Edward Gordon Craig's theatrical thought can be solved if they are approached as a pragmatic construct that takes the form of a concentric system that revolves around mystic contemplation, and each layer of which is a more or less remote surrogate of such contemplation. By detailing each of these layers in its relation to the core of that concentric system, the paper eventually proposes an overall synthesis of the aesthetics of Craig's experimentations.
\end{abstract}

Keywords: Edward Gordon Craig. Aesthetics. Mysticism. Theater and Religious Thought. Philosophical Aspects of Theatrical Thought.

RÉSUMÉ - Les Contradictions de Gordon Craig - Les apparentes contradictions de la pensée théâtrale d'Edward Gordon Craig peuvent être résolues si on les approche comme une construction pragmatique qui prend la forme d'un système concentrique tournant autour de la contemplation mystique, et dont chaque couche constitue un succédané plus ou moins lointain de cette contemplation. En détaillant chacune de ces couches dans le rapport qu'elle entretient avec le cœur de ce système concentrique, l'article propose, au bout du compte, une synthèse globale de l'esthétique des expérimentations de Craig.

Mots-clés: Edward Gordon Craig. Esthétique. Mysticisme. Théâtre et Pensée Religieuse. Aspects Philosophiques de la Pensée Théâtrale.

RESUMO - As Contradiçóes em Gordon Craig - As aparentes contradiçóes no pensamento teatral de Gordon Craig podem ser solucionadas se forem abordadas como um constructo pragmático que assume a forma de um sistema concêntrico que gira em torno da contemplação mística, sendo que cada camada constituem um sucedâneo mais ou menos remoto dessa contemplação. Ao detalhar cada uma dessas camadas em sua relaçáo com o âmago desse sistema concêntrico, o artigo propóe, por fim, uma síntese global da estética dos experimentos de Gordon Craig.

Palavras-chave: Edward Gordon Craig. Estética. Misticismo. Teatro e Pensamento Religioso. Aspectos Filosóficos do Pensamento Teatral. 
Gordon Craig's theoretical thought is a highly complex construction. He expressed it through his very few productions, of course, but, more importantly, his designs, woodcuts, etchings, and above all, his many writings. But these writings are often found to contradict themselves: his detractors use those self-contradictions to deride and minimize his contribution to modern theater, while even his partisans admit that it may prove difficult to determine what his position actually was as to a given issue. Did he seriously intend to get rid of actors altogether, or did he approve of their presence on stage? Did he favor marionettes, or only Über-marionettes - whatever that term may have meant? Did he reject literary plays as the basis for theatrical productions, or did he tolerate them? Lee Simonson, his harshest opponent, wrote that his essays were "[...] a mass of evasions and contradictions" (Simonson, 1931, p. 19-20; apud Innes, 1998, p. 5), and "[...] a medley of methods, a hodge-podge of guesses" (Simonson, 1932, p. 335; apud Sheren, 1968, p. 189). Irène Eynat-Confino admits "[...] that his retractions and his ambivalent attitude toward the actor [...] do not facilitate the task of the scholar in quest of 'truth"' (1987, p. x). Christopher Innes confesses that "[...] there are many contradictory elements [in the way Craig's ideas are expressed], some of which were never fully resolved. [...] Critics have used such contradictions as arguments for dismissing Craig's vision", an assertion that is immediately qualified as follows: "But these ideas have an inner consistency, and in light of this almost all of his innovations and theories [...] which otherwise seem eclectic, are clearly integral parts of a whole" (1998, p. 175).

\section{A Pragmatic Consistency Behind Seeming Contradictions}

That "inner consistency" struck me, when I was in charge of the Edward Gordon Craig Collection in Paris, from 2006 to 2009, as a hallmark of Craig's contribution to the theater; and even more so than Craig's so-called contradictions. My everyday frequenting of Craig's huge archives allowed me to discover an extremely well articulated mind, characterized by pragmatism - quite far from the usual cliché of Craig as an eerie and totally impractical theoretician. In my opinion - with which, of course, readers are free to disagree - it is Craig's pragmatism that makes it possible to explain his apparent inconsistencies and solve his very contradictions. This pragmatism 
is based on a very simple principle, which can be paraphrased as follows: One should aim at an ideal; if that ideal proves impossible to reach, then one should aim at something slightly less ideal; and if that slightly less ideal thing cannot be reached... - and so on and so forth.

That simple principle leads to the development of a concentric structure, with the ideal thing at its core, and the least-ideal-but-stilltolerable thing at its periphery. A circular chart of Craig's theatrical thought, as it were.

Surely, Craig never drew that circular chart explicitly, and what follows is a mere attempt at (re)constructing it. However, I felt authorized to make that attempt, because of two texts written by Craig himself, in which I think he expressed something of that pragmatic attitude.

In A Plea for Two Theatres, Craig admitted that two very different theaters could coexist harmoniously in a utopian future: a durable theater (based on religious ceremonies), and a perishable one (based on commedia dell'arte-like improvisations). Although he asserted that the perishable theater was not "inferior" to the durable one, only "different" (Craig, 1919, p. 18), there is clearly some notion of hierarchy in that distinction, as "The ephemeral is the work of young people, and the durable is theirs also, when they shall have passed through youth. Thus the one would be a training for the other" (Craig, 1919, p. 24-25). But the most interesting aspect of that essay for the present argumentation lies in the fact that Craig also expressed in it the idea that it would be vain to strive to raze down the commercial theater, which even in that utopian future might well coexist with the other two theaters: "Please do not imagine that I am quixotically inclined; that I am wanting to run a tilt against the theatrical trades who supply the goods which ultimately pile up into this pyramid of trash" (Craig, 1919, p. 7). There is no need for exclusive, totalitarian aesthetics of the theater, because "There is something good in every theatre - something, not everything" (Craig, 1919, p. 32).

Craig's pragmatic relativism is even more forcefully expressed, I argue, in The Art of the Theatre: the first dialogue (2009):

PLAYGOER: Then do you mean to say Hamlet should never be performed? 
STAGE-DIRECTOR: To what purpose would it be if I replied 'Yes'? Hamlet will go on being performed for some time yet, and the duty of the interpreters is to put their best work at its service. But, as I have said, the theatre must not forever rely upon having a play to perform, but must in time perform pieces of its own art (Craig, 2009, p. 75-76).

Thus, even though it is preferable, more in accordance with the ideal thing, not to "rely upon having a play to perform," it remains permissible, at least for some time, to put Hamlet on stage. This is what I labeled the pragmatic "concentric structure" at work, which explains why Craig eventually accepted Stanislavsky's invitation to direct Hamlet in Moscow.

It would be wrong, however, to imagine that that concentric structure existed in Craig's mind once and for all, and never evolved over time. Surely, it did evolve over time, and some of its more central layers appeared later than some of its more peripheral ones: its development was neither centrifugal nor centripetal, but its various layers were put in place rather randomly, as new ideas popped up in Craig's mind.

I will first introduce briefly what those layers were, from the core to the periphery; then I will elaborate on them more at length, going back from the periphery to the core.

\section{The Concentric Structure of Craig's Thought in a Nutshell}

I regard Gordon Craig as essentially a mystic, who placed God at the core of his system of thought. Surely, that God is not a God who can be approached through dogma or theological reasoning, but a God who has a strong connection with the theatrical notion of spectacle: the direct contemplation of God by an individual is the ultimate and unsurpassable show.

If such direct contemplation is denied to you, you always can content yourself with the contemplation of a symbol for God, by watching the slow movements of shadows cast on city walls by the sun: this is the next-to-ultimate show.

If you are not patient enough to stand such a slow and lengthy spectacle, you can content yourself with a surrogate of that symbol for God, by watching the movements of Craig's kinetic stage, which elaborate on the slower movements of natural shadows. 
But Craig's kinetic stage was never built: so, what can be done? You can try an Über-marionette show. Über-marionettes still stand as symbols for God, although they are of a far coarser nature than the immaterial, metaphysical shadows that the kinetic stage was to make visible, had it been realized.

But where is an Über-marionette show to be seen? Even that was a failure. Why not try just ordinary puppets? Even though they degenerated, they stem from divine descent: in a remote past, they were idols, and they still are images of gods in some Asian cultures. Watching them as they move is like watching embodied deities.

However, other possibilities are left, although they lead us even more astray from direct divine contemplation. Art theater is potentially illuminating, when stage-directors are inspired by God. But the condition for such a result is that stage-directors must be in absolute control of everything that happens on stage: even actors should not be more than mere puppets in directors' hands for theatrical productions to be regarded as everlasting works of art that convey spiritual notions.

If stage-directors are not genuinely inspired by God, or if actors are not willing to be reduced to puppets, or if it proves unfeasible, for some reason, to exert absolute control on the stage, then other possibilities remain open. A creative theater is an acceptable option. The difference between art theater and creative theater is that the former is produced by stage-directors, while the latter is performed by actors. In creative theater, there are no stage-directors: it is entirely ruled by actors, as it is based on improvisations. As already mentioned above, it can be either profane (the "perishable" theater) or religious (the "durable" theater); but in either case, its creative nature still links it to God. Creative actors reenact the Creation.

But Craig lamented that, in his life-time even that kind of creative theater did not exist any longer (or had not been revived yet). The good old Victorian theater - Henry Irving's theater, Ellen Terry's theater - still was an option to be remembered. That theater could still be cherished, even though Craig never argued that it should be imitated or prolonged. And beyond it, the whole territory of theater history was to be charted. Studying theater history amounts to looking for the creative sparkles that existed in past centuries. Therefore, it still has to do with the quest for a Creator. 
And then, there is the commercial theater - the least acceptable, although not entirely unacceptable, option. This still is theater, although it has so little to do with divine contemplation. Pragmatism can extend so far, provided it remains aware that it is the most external circle of a tight concentric "solar system." It is not to be regarded as an end in itself, not to be desired; it is just a "pot-boiler," a source for income, when everything else has failed. It is impossible to stray farther from God.

\section{Craig's Journey in His Own System}

\section{The Commercial Theater}

Craig made only two attempts to tread the slippery ground of the commercial theater: once in 1908-1909, when he planned to collaborate with Herbert Beerbohm Tree on a production of Macbeth in London, and the second time in 1928, when he designed the sets for Douglas Ross's production of Macbeth (again) in Philadelphia and New York.

Herbert Beerbohm Tree was a frequent target for Craig's sarcasms, but not only his; as Cary DiPietro puts it:

For those who campaigned variously for the reform of the theatre, Tree's Shakespeare productions not only epitomized an outmoded histrionic style of acting largely descended from Victorian melodrama, but the unmitigated commercialism of his ventures was seen to accommodate the predominantly bourgeois tastes of his audience. Actor-managers such as Tree were seen to have reduced Shakespeare to the level of expensive spectacle and pageantry, sacrificing their integrity to the 'profit-seeking stage' (DiPietro, 2006, p. 92).

What motivated Craig to accept the principle of collaborating with such a man was, according to Denis Bablet, his hope that it would serve a good cause: "Though not in the habit of restricting himself to designing a production, Craig agreed because he thought it would help him to raise money for The Mask" (Bablet, 1966, p. 95).

But in 1928, when Craig accepted to design his "[...] only American production," as Paul Sheren labeled it (Sheren, 1968, n.p.), it was merely in order to earn a living: "[...] all he wanted was the money. When he signed his drawings 'C.pb' he confidently imagined that posterity would realize that his work was to be excused because it was a 'Craig-potboiler"' (Craig, 1985, p. 330). 


\section{Victorian Theater and Theater History}

The stage of Henry Irving's Lyceum Theater was the school in which Craig learnt everything about the theater. And the Lyceum Theater epitomized the essence of Victorian theater. Craig was the son of Victorian theater; as any son, he both rebelled against his progenitor, and felt irresistibly attracted to it. He believed it was utmost degenerated, but could not help cherishing it all the same. He raised Henry Irving to a standard against which his own outcomes were to be measured.

Craig's obsession with Victorian theater, that beloved enemy, lasted for his entire life. In 1956, when he was 84 years old, he drew sketches for a production of Shakespeare's Tempest that was to be set on the empty stage of the Lyceum such as he knew it when a teenager and a young actor, "[...] a tangle of ropes and shadows" (Le Boeuf, 2013a, p. 236).

Actually, Craig was fond of any long-standing theatrical tradition that created links from a decadent present to a more glorious past. In an article devoted to Tommaso Salvini, whom he met in January 1913, he reported that the great Italian actor admitted that the stage in Italy might have deteriorated since the years of his training:

I then asked him whether he would also go so far as to say that he believed that when he was a young man the stage had deteriorated from the stage of fifty years previous to that time.

Salvini looked perhaps a little bit suspicious as to what that might mean, [...] but in the end he said, 'I am inclined to think that such was the case' (Craig, 1919, p. 216).

Craig's intention in such a passage is not so much to blame the present-day stage of decadence of the theater, as to insist on the notion that the entire history of the theater, from its farthest origins up to the present day, is one of steady, irresistible decadence. He believed as much as Heinrich Kleist in the infelicitous consequences of the Fall: "It seems to me that we should not forget that we belong to a period after the Fall and not before it" (Craig, 2009 , p. 23). Paradise has been locked since we ate of the tree of knowledge. Craig's compulsive activity as a theater historian aims at the discovery and recreation, not of the theater of the past, but of the conditions that surrounded a hypothetical, idealized theater 
anterior to the Fall, through the thread that leads us seamlessly from our degenerated theater to pristine forms of art that were as close as possible to the pre-Fall condition of humanity. The study of theater history is part of such a mystic quest, which is its only justification, since the mere recreation of the past for its own sake is totally valueless, in Craig's view.

\section{Creative Theater}

Creative theater is made by actors - free and imaginative actors, who are able to extemporize, and to produce masterworks as they extemporize. Craig believed that such actors had existed in the past, and could exist again in the future. He went so far as to assert that Shakespeare's contribution to the plays attributed to Shakespeare consisted mainly of polishing actors' improvisations:

Indeed, much of the Elizabethan Comedy is the work of the actors, produced in that spontaneous manner; many of those brilliant flashes of genius which have helped to give Shakespeare the position he holds today were first struck out in the sharp encounter of wits on the boards of the stage. [...] We may quite easily believe this - as everyone who has studied the history of the 'Commedia dell'Arte' will believe it [...] (Craig, 1919, p. 120).

Commedia dell'arte stood high in Craig's opinion, and he published many articles about it in The Mask. As Olga Taxidou puts it:

Like his Modernist contemporaries (Meyerhold, Copeau, Diaghilev), Craig saw in the Commedia an ultimate remedy to the damage done to the theater through naturalism. [...] At a time when scholarship on the Commedia in English was limited, The Mask proves to be a vital source book for the Italian improvised theater (Taxidou, 1998, p. 111-113).

Craig's notion of "a perishable theater," as already mentioned above, is very much based on the revival of Commedia dell'Arte. Both the "perishable theater" and its religious counterpart, the "durable theater," were thought by Craig to be creative theaters of the future.

Craig regarded Music-Hall and Circus as two contemporary equivalents for Commedia dell'Arte: he despised neither, because he found in both the creativity that, according to him, the literary 
theater of his day was missing so badly. In his unfinished and unpublished essay titled An Easy Book on the Theatre, he affirmed:

These clowns I consider of more value to the Theatre and its Art than all the plays written by Mr. Brieux, Mr. Shaw, Mr. Strindberg, Mr. Ibsen, Tchekhov, or Messrs. Pinero, Sutro, Jones, Barker, Goethe, Shelley, Byron, Browning [...]. The clowns make their joke, or drama, or show (call it what you will) out of nothing, and they make it themselves. They cannot tell you how they make it, but they can teach you to make it too, if you have sense (Craig, 1922, p. 145r).

Craig was therefore not necessarily an enemy of actors - or, more broadly speaking, performers; a theater of actors was potentially valuable, provided it was genuinely creative. But even so, it was doomed to lie farther from divine contemplation than a theater of stage-directors, an artistic theater.

\section{Theater of Art}

In contrast with performers, stage-directors, in Craig's system, are genuine artists: they have a vision, which they translate into a concrete language, in the course of a creative process analogous to that followed by painters, sculptors, and composers. It is that artistic vision - directly inspired by God - that provides a closer connection between directors' theater and divine contemplation, than between actors' theater and the latter.

Craig's conception of theatrical productions as works of art ascribable to individuals rather than ensembles derives from his activity as a wood-engraver and his reflections on painting and architecture. Wood-engraving involves tremendous physical efforts for the artist's internal vision to be embodied in the matter of the woodblock. Such physical efforts are an act of creation, and Craig intended to recreate the same type of creative act on stage. He quoted this motto from Gustave Flaubert: "The artist should be in his work like God in creation, invisible and all-powerful" (Craig, 2009, p. 37).

The independence of theatrical art is a requisite for the fulfillment of its religious objectives. Once genuine artists of the theater have managed to break the yoke imposed on theaters by playwrights, musicians, and scene-painters, then:

[...] there shall spring so great an art, and one so universally beloved, that I prophesy that a new religion will be found 
contained in it. That religion will preach no more, but it will reveal. It will not show us the definite images which the sculptor and the painter show. It will unveil thought to our eyes, silently - by movements - in visions (Craig, 2009, p. 64).

Those visions have to do with perceptions of a supernatural world, in the same vein as the mystico-poetical visions evoked in Samuel Taylor Coleridge's The Rime of the Ancient Mariner:

[...] an old and troubled mariner once came to me to tell of an island placed beneath the sea - a sunken island [...] In such an isle full fathoms five indeed our fathers lie. [...] 'And what,... what did happen to you down there?' [...] He looked at me [...] and then lowering his eyes went away apparently eased of all his trouble at the perfect remembrance. [...] Something very beautiful to see and to hear must have been what he heard and saw. [...] What happened under the sea in an island known to none but he, is what I should like to make visible in The Tempest upon a stage [...] (Craig, 1925, p. 163-164).

Mystical symbols are scattered all over Craig's scenes in order to provide that indispensable link between the audience and the supernatural world that performances are meant to unveil. In accordance with Plato's notion of God as an eternal geometrician, these symbols are often pure geometric forms (Eynat-Confino, 1987, p. 132-139; Le Boeuf, 2009, p. 22-26): squares, cubes, parallelepipeds; circles and spheres; and, less frequently, triangles and pyramids. Stairs symbolize the soul's ascent to a spiritual realm. And Craig's obsessive leitmotiv of incredibly dense crowds bearing a huge number of erected spears or staffs pointing to the sky echoes Egyptian phallic processions in honor of Bacchus/Osiris, such as Charles Magnin described them (Magnin, 1852, p. 11-12), and such as Craig himself is reported to have evoked them: "[...] the forty thousand people on a Greek hillside, watching in the clear Attic sunshine a phallic procession [...]" (Flanagan, 1928, p. 72).

However, no matter how artistically and spiritually successful such productions can be, they still are inferior to forms of theater that are entirely deprived of the impure presence of the human body on stage. 


\section{Puppet Shows}

Craig took puppets quite seriously. For him, the marionette was not something that "[...] is only for boys and girls" (Craig, 1919, p. 100); on the contrary, "There is only one actor - nay, one man - who has the soul of the dramatic poet and who has ever served as true and loyal interpreter of the poet. This is the Marionette" (Craig, 1919, p. 93).

Craig was not the first one to be interested in the marionette's potential for a metaphysical theater. Prior to him, the Symbolists already had expressed the same enthusiasm: "[...] they were interested in the stiffness of marionettes, precisely because it prevented them from imitating life, and deprived the theatrical art of its 'naturalistic' potential" (Losco-Lena, 2010, p. 40; my translation). While an actor's face cannot exhibit anything but the idiosyncratic features of a given individual, a merely fortuitous instantiation of a universal, the intentional work of art that a marionette's face is tends, like any work of art, to reflect directly the very essence of that universal, by stylizing it and reducing it to just those few consciously selected features that are necessary to convey it accurately and efficiently. A puppet show is therefore closer to the metaphysical contemplation of divine truth than any theatrical show involving human actors can ever be. The manipulator who blows life into those small wooden or ivory beings has a homothetic relationship to God. The spectacle of marionettes coming to life through the action of the manipulator's hands is a symbol for the spectacle of the entire Creation.

For Craig, the marionette is essentially a religious device, the degenerated image of a deity:

You have come across him in some deserted cathedral in Italy or even in England [...]. There you will have seen him hanging upon the Cross. And many Christians love him; he is interpreting the Drama of the Poets - Man and God. Or you have caught a glimpse of him in some temple in the Far East, enacting a more serene drama - seated before incense - hands folded - very calm (Craig, 1919, p. 94).

As already mentioned above, Craig was perfectly aware, through his reading of Charles Magnin's history of puppets, that the most ancient marionettes were articulated phalluses used in Egypt for processions in honor of Osiris (regarded as an equivalent for Bacchus): 
"[...] he [the marionette] figured in the Feast of Bacchus when the Egyptians celebrated those rites" (Craig, 1919, p. 100). He also knew, from Lindor Serrurier's study on Javanese shadow puppets, that such puppets often exhibit phallic symbols, most notably the Semar character (Serrurier, 1896, p. 182), whose name he chose for himself as editor of The Mask. Serrurier's study is in Dutch, but the wife of Michael Carmichael Carr, one of Craig's collaborators in Florence in 1907, was Dutch, and she translated for him some passages of that book (Craig, 1985, p. 233). Craig's copy is now in the Craig Collection in Paris (Fol-EGC-83), and English translations of some passages in which Serrurier explains the phallic symbolism of Javanese puppets are penciled in the margins. For instance, she wrote, in her exotic English, that "[...] mostly giants or people of supernatural force have phallisian hands" (Serrurier, 1896, p. 183). An entire chapter of Serrurier's book is devoted to phallic symbolism (1896, p. 291-307), but there are no handwritten translations in the margins.

For Craig, puppets still retained something of their phallic origin. Just like in Eastern puppetry, the marionettes that Craig had carved by his collaborators were endowed with male genitalia, because they were images of gods and therefore had to have complete bodies. On 5 February 1915, he jotted down a draft for a marionette's (rather disturbing) soliloquy about the sacred and profane members of marionettes' bodies. This unpublished draft is to be found in manuscript EGC-Ms-B-1382 of the Craig Collection in Paris:

The two sides of a face, two ears, two lips, two arms, two hands, two legs, two feet - two of most things. One is profane, one is sacred. When I wink, it's with my profane eye - that's my left eye. When I sneeze - only one nose, but then a member of the Privy Council, or the editor of the Daily Mail, can sneeze; so it must be put on the side of the sacred members. One chin, and one unruly member which must not be mentioned - yet, now I think of it, why not mention it? It is long, duro, forte, eretto, l'ombra dello papa... I allude to my tail? I have but one tail, nose $[. . .]^{1}$ (Craig, 1915, p. 45r).

The First Prologue of Craig's Drama for Fools is written for two marionettes. In one of the manuscripts, dated October 1914 (reproduced in Innes, 1998, p. 299), there is an interesting detail which Craig did not incorporate in later typescripts of the play: "The second marionette has no sex" (Craig, 2012, p. 73). As the 
play unfolds, the first marionette - i.e., then, the one whose male genitalia are explicitly carved in wood and visible - reveals its true nature: "I am an Image... the Image of a God. I am therefore a God to those who believe in me. [...] I can know nothing about God. My duty is that of an Image of God... [...] I am an Illusion and a Reality" (Craig, 2012, p. 70).

The non-sexed (although male-shaped) marionette is therefore but an image of Man, while the presence of the other marionette's phallus is a sign, or a warrant, of its divine resemblance; such a sign is a requisite for a supernatural manifestation to be possible on stage.

\section{Über-Marionettes}

The world lacks and needs a Belief. A childish one - one full of complicated customs and ceremonies. Think of the belief which possessed the Egyptians - which made them perform all the ceremonies, all so childish and lovely, of the dead and for the gods, and for the Nile, and for all the rest of it. A Belief full of Beauty: that is what I will try to find for myself, and then for the world - passing it to them by means of my Über-marionettes (Craig, 1905-1906, p. 4v).

These are the words in which Craig expressed the intended purpose of his invention, the Über-marionette. Although Craig refers here explicitly to Egypt - again - it seems that the idea for the über-marionette either popped up in his mind or found supporting confirmation while he was reading Karl Mantzius's description of ancient Greek actors' costumes:

That these strangely equipped large figures with their immovable faces, which seemed petrified with suffering, and in their gorgeous splendour, advancing slowly with solemn measured movements, must have produced a powerful and romantic impression on the minds of the naïve ancient Greeks, we can easily imagine. They must have appeared almost like living images of the gods, and when the people heard the beautiful grave words emanating from these walking statues, they were seized with artistic as well as religious enthusiasm (Mantzius, 1903, p. 187).

This description gave birth, in Craig's imagination, to "[...] an actor encased in a sort of armor, so he could make none but graceful, slow, sweeping gestures", by the account of an eye-witness, Craig's Californian collaborator Michael Carmichael Carr (Le Boeuf, 2013b, p. 57). 
The performer within the Über-marionette is similar to the soul within the body: it makes it move while the source for such miraculous motion remains indiscernible for those watching it. The same way as an invisible God's action can be perceived through the movements of celestial bodies and living beings, the same way an invisible stagedirector's action can be perceived through the movements of lightings and Über-marionettes.

A frequently reproduced drawing of an Über-marionette (e.g., in Eynat-Confino, 1987, p. 81; Freixe, 2010, p. 41) shows that it was to move among a number of square-section posts, approximately half the size of a human body. In his manuscript devoted to the Übermarionette, Craig wrote: "For the manipulation of the two cloaks, a couple of attendants on the actor, who place them ready for him to manipulate further: on a post here, or there a post. The posts are also moveable by the attendants. The posts will be different sizes, colours, shapes" (Craig, 1905-1906, p. 4v). In addition to being a device for elegantly disposing props and costume elements, it can be presumed that these posts were also meant as phallic symbols; as such, they warranted that a spiritual manifestation might take place on stage.

\section{The Kinetic Stage}

The circumstances under which Craig had the revelation of the kinetic stage in February 1907 are well known (Craig, 1985, p. 233-239; Bablet, 1966, p. 118-119; Innes, 1998, p. 177-178; Spieckermann, 1998, p. 231-232): while looking at a woodcut from Sebastiano Serlio's Architettura, he had the idea of a scene consisting of vertical square-section columns moving up and down and allowing for the purest expression of absolute drama through their "abstract movement" (Craig, 1985, p. 233). Today, we would tend to label that kind of theatrical form posthumanistic, but in Craig's mind it embodied, rather, the idealized pre-Fall theater he aspired to retrieve. Not a scene, therefore, for times after humankind, as the term posthumanistic implies, but a scene that reminds us of times before humankind stepped down from its state of Innocence. That such a scene had a mystical significance for Craig is made quite clear in the notes that he jotted down on his copy of Serlio's book, and in the scripts that he wrote with the intention of having them performed by his kinetic stage, once he had built it - which, as readers know, 
never happened. In a scene consisting exclusively of phallic symbols, God is assuredly everywhere to be perceived and manifest himself.

For lack of an actual kinetic stage (a phrase he never used), Craig strove to disseminate his visions through two series of etchings, some of which were reproduced in Scene in 1923, together with an essay on the history of scenery. But here we are faced with a very peculiar self-contradiction, which has been stressed by Christopher Innes in these terms: "On one hand, the thrust is away from actors to puppets and finally to abstract movement. On the other, Craig stresses the value of his concept as a context for human figures. [...] Indeed, [...] of the nineteen etchings published in Scene only two show geometric shapes without human figures" (Innes, 1998, p. 175-188).

Surely, this is Craig's most interesting - and puzzling contradiction. Why did he introduce human figures in his pictures of a scene that was meant for abstract movement only? Were those figures intended as an indication for scale? This is very unlikely. Were they really intended to depict human performers? Some of them look very much like über-marionettes, and could therefore be regarded as receptacles for human manipulators. But many others seem somewhat odd as human beings: they are mere shadows, bizarre shapes, tiny beings at risk of being crushed by the huge columns that surround them, or of falling from the narrow platforms on which they stand. I am very much tempted to see in them, not actual performers, but, rather, those supernatural beings that Craig intended to behold "[...] not with the eye, but through the eye", as William Blake put it (a line that Craig quoted over and over again, obsessively, in a huge number of his writings): apparitions only to be imagined, not realized. The very purpose of the kinetic stage was precisely to conjure up such apparitions. Craig shows us here simultaneously the technical means and the expected metaphysical result.

\section{Sunshine and Shadows}

When Craig published On the Art of the Theatre in 1911, he wrote a brief text titled God Save the King especially to the purpose of serving as a general foreword to the entire collection of essays (most of which had been previously published as articles). God Save the King is not an expression of Craig's adherence to royalism; it is a mystical text about divine symbols: "If there is a thing in the world that I love 
it is a symbol. If there is a symbol of heaven that I can bend my knee to it is the sky, if there is a symbol of God, the Sun" (Craig, 2009, p. xxviii). The sheer contemplation of the Sun, whether directly, or indirectly through the contemplation of the moving shadows that it casts on the world, is a symbolic way to contemplate God:

[...] seeing this daily glory, this Sun, I know that the miracle comes and goes, that the miracle is just the passage of this symbol of the Divine, this seeming motion of the Sun from east to west. And that seeming motion of this God is enough for man to know (Craig, 2009, p. xxx).

For Craig, the most beautiful spectacle in the world consisted solely of sitting on an Italian piazza, and watching the slow movement of shadows from dawn to dusk. In an unpublished draft for the second part of his memoirs, Craig described how impressed he had been in his youth, while attending a spectacle directed by William Poel, by the effect of the sun on the wooden walls of the Elizabethan hall in which the performance was taking place - much more so, indeed, than by the show itself:

I [...] felt the value of these carved wooden walls, intricate and massive, full of lights and shadows, coloured by the sun's rays as they moved along the face of these splendid carvings. 'No scenery?' - why, never was such scenery before, except in Shakespeare's day: in place of painted canvas cloths were sculptured walls. It was a blaze of beauty, of rich sparkling beauty, against which moved the actors [...] (Craig, 1950, p. 6-7).

Ultimately, Craig's system of thought looks very much like a continuous chain of symbolizations: the movements of actors, puppets, or Über-marionettes, are a surrogate for the abstract movements of the kinetic stage; these abstract movements symbolize the movements of shadows cast by the Sun's rays; these movements are a sign of the seeming motion of the Sun; and this seeming motion of the Sun reflects the inscrutable action of God in the process of Creation.

God

Craig was not a Christian, and never was a member of any established Church: "I then spoke of the difficulty I had in being a 'believer' in the sense the Catholic uses the word. I said I had tried hard, but the Church was always preventing me by force from loving 


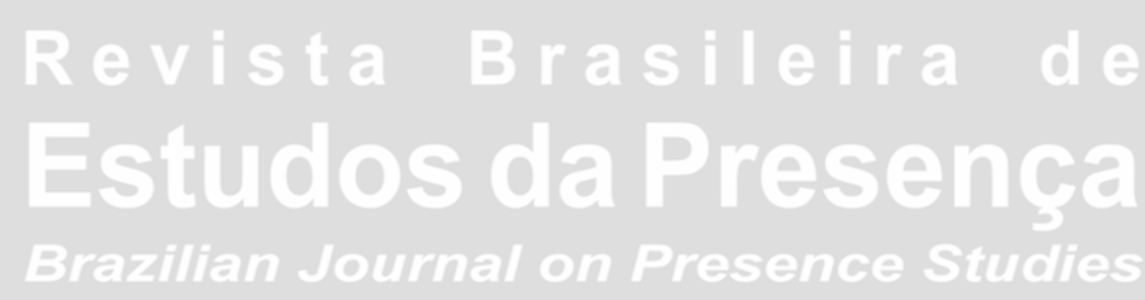

the Church" (Craig, 1919, p. 165). However, the direct mystical bond between God and the individual was his main preoccupation. Although he affirmed it was impossible to see God's face - "What then is this mysterious thing which is eternal, which creates itself, which keeps the world spinning, which never grows old or gets tired? No one has seen its face and lived" (Craig, 1919, p. 61) - he aspired to experience revelations, and reproduce them on stage.

But he was very much aware, too, that his aspirations to mysticism put him at risk of being sent to a lunatic asylum. Hence his extreme prudence and discretion: more often than not, he refrained from publishing texts that were too overtly exalted, and confined the expression of his religious ideas to his manuscripts and his correspondence with his bosom friend John Paul Cooper, the Arts and Crafts designer, who shared his craving for mystic revelation. Even his correspondence with William Butler Yeats does not reveal anything of this religious thinking, which is astonishing, as there are some similarities between the two men's relations to the divine: Yeats wrote, for instance, that "[...] my Christ [...] is Blake's 'Imagination" (apud Harper, 2006, p. 146).

It seems well that the two main sources for Craig's mysticism were poems by William Blake and Walt Whitman. As Pierre Pasquier puts it: "Craig's aesthetics follows faithfully any single transport of Blake's untamable spiritual demands" (Pasquier, 1984, p. 228; my translation). Craig was as much impressed as Yeats by the way Blake used the term Imagination. On his copy of a book devoted to Bahaism, he jotted down the following unpublished notes:

I have discovered the secret of perpetual motion: it is in the Imagination - it is the Imagination. Others have discovered this before me. Yet no one has acknowledged that the thing is accomplished. The centre of the wheel which incessantly moves is $\mathrm{God}^{2}$.

In one of the few mystical texts that Craig dared to publish, he went so far as to write: "Love and Imagination. What are these two but the face of God and its reflection in the mirror?" (Craig, 1919 , p. 62). In a sense, Imagination is even superior to God, and the following sentence, which Craig included in an article signed Britannicus that he published in The Mask, raises a certain amount of doubt as to whether Craig did really believe in the actual existence 
of the God he worshipped nonetheless: "When we talk of God we allude to a creation of the Imagination; without the Imagination God could not exist" (Craig, 1912, p. 7).

At any rate, Craig eventually managed to experience the visions he craved for. On 17 November 1908, he had an illumination, which he described in these terms:
Light
All is clear suddenly
The only secret mysterious profound truth is the simple light and the Heart of that, the Sun -
Where I sought for motion I was meaning Light
The Sun is our only God [...].

The complete text of Craig's account of his 1908 illumination has been already published by at least three scholars (Rood, 1971, p. 96-97; Eynat-Confino, 1987, p. 175-177; Spieckermann, 1998, p. 33, p. 296-297). In addition to that textual account, Craig made, on his copy of Walt Whitman's poems, a drawing (reproduced in Le Boeuf, 2009 , p. 19) depicting the sun, within which a square and a triangle are circumscribed. Circle, square, triangle: the three geometric forms that make up the basis for Craig's scenic vocabulary.

The significance of that illumination for Craig is best illustrated by the following two paragraphs, incorporated by Craig in the catalogue of an exhibition of his etchings that took place in Florence just a few weeks later:

Until quite recently I was under the delusion that in some way the Theatre was connected with my vision. [...] But I know now that this art about which I write and to which I have given my life, transcends the Theatre. This has been made clearer to me only quite recently. [...] I hope to be able again to serve as intermediary between you and the Power which I obey - to reveal more clearly the mystery of the Light and the Shadow which creates the illusion of Motion. I hope that I may in time show many more of the things which I have seen. Chiefly Light - Light - the vast and the tiny Spaces - the sweet and the pretty Motions as well as the grave and gloomy - the buoyant - the glowing - all that I can (Craig, 1908, p. 10-12).

Craig still was to have subsequent similar illuminations: one night of April 1910, he saw a light hanging above him and containing "[...] a kind of arabesque" (Spieckermann, 1998, p. 33-34); on 5 November 1911, a vision confirmed the one he had had in 1908 
(Spieckermann, 1998, p. 33); and on 8 May 1913, he titled Third Illumination a script for his kinetic stage, followed by a prayer to God (Spieckermann, 1998, p. 300-301).

Craig related these illuminations to what he had read in a book that seems to have been very influential on him: Richard Maurice Bucke's (now somewhat ill-famed) Cosmic Consciousness (1901). In that book, Bucke, a friend of Walt Whitman's, developed the pseudoDarwinian idea that cosmic consciousness was some kind of a sixth sense that humankind is bound to acquire over time through a process of natural evolution; some individuals, such as Jesus, Buddha or Walt Whitman himself, were supposed to already have acquired it, on the occasion of spiritual illuminations. Craig's copy of that book is no longer extant today, because he lent it to someone (probably Isadora Duncan, although I have not found physical evidence for that) at one point between 1901 and 1907. But in an unpublished letter to John Paul Cooper, dated September 1907 (now in the Craig Collection in Paris), he advised his friend to read it, and wrote an abstract of it for him. Incidentally, Cooper is known to have performed, in November and December 1907, under the lead of a psychic, a series of mental exercises in order to achieve cosmic consciousness (Kuzmanović, 1999, p. 60).

That pseudo-Darwinian approach to spirituality leads me to formulate this hypothesis as to what the ultimate purpose of Craig's theater was meant to be: Could it not have been to speed up that evolutionary process through which humankind was supposed to acquire cosmic consciousness? By materializing on a stage the visions he received from supernatural entities, was it not Craig's intention to enlighten the audience as well, and provide them with the power to discover in themselves that ability to establish a spiritual connection with the Universe? In that prospect, the objective of Craig's theater would have been to help a little the natural, Darwinian evolution of humankind toward a spiritually enlightened species.

\section{By Way of Conclusion}

High Modernism has a surprisingly closer relation to the sacred than we tend to imagine - or are willing to accept. "The Modernists were not the devout secularists that many critics portray," and such High Modernists as James Joyce and Virginia Woolf "[...] 
continued to search for an adequate account of religious experience, a kind of essence of religion without God or church, and this search contributed to the development of literary Modernism" (Lewis, 2011, p. 181-182). William Butler Yeats cherished above all "[...] the very personae that critics have tended over the years to make the most marginal and capricious: Yeats the hermeticist, the theosophist, the magician, the spiritualist, the occult metahistorian, or the seeker after Celtic or Indian mysteries" (Harper, 2006, p. 146). T.S. Eliot converted to Anglo-Catholicism in 1928.

Literature was not the only domain in which Modernism expressed an interest in spirituality. In 1910, Wassily Kandinsky wrote Concerning the Spiritual in Art. In October 1916, the composer Ivan Wyschnegradsky experienced an illumination, for which he accounted in terms similar enough to those used by Craig: "And colors disappeared, and there was only the light, absolutely pure, an infinite light. There was no time, and so it was for two months" (apud Criton, 2009, p. 33). Craig's theatrical thought is just another example for that entanglement between High Modernism and religious preoccupations. His flowery mystico-poetical texts are often harshly criticized, even by historians, who should strive to explain them, rather than deride or reject them: "Slightly less embarrassing than once it may have seemed, is the best one could say. Craig was no poet, not prose-poet" (Franklin, 1980, p. 72); "[...] the pretentious amalgam of symbolic action and religious service is unconvincing" (Innes, 1998, p. 193); "Some of the elements of his Art of the Theater would have dated badly. Others - in particular, the quasi-religious material around which his later theatrical forms became centered - would have seemed unacceptably pretentious or too far removed from contemporary consciousness" (Innes, 1998, p. 213).

Surely, we may think what we will of Craig's pretensions to mysticism. Surely, we may opine that he badly needed psychiatric care. Surely, we may even deem that the poetic expression he strove to confer to his spiritualistic convictions was less than appropriate. Surely, we are not asked to adhere to his religious (and even less so - Heaven forefend! - political) opinions. But, after all, Craig's spiritual, or pseudo-spiritual, ravings were not quite so acute as those of many of his contemporaries: he never indulged in writing and publishing such a delirious book as Yeats's $A$ Vision (1925); he 
never mentioned the name of Helena Petrovna Blavatsky, whom so many of his fellow artists admired so much; and as far as I know, he never took part in a séance, although he happened to see ghosts two or three times in his life.

More importantly, dismissing entirely the religious aspects of Craig's aesthetics and theatrical thought, and ignoring altogether their close relationship to similar currents of Modernism, represents, in my opinion, the best means not to understand Craig - the same way as ignoring the relation of Modernism to the sacred represents the best means to fail to fully understand Modernism. 


\section{Notes}

${ }^{1}$ In the manuscript this text is followed by the word Tiger within brackets. One of Craig's favorite items in his collection of puppets was a Burmese tiger marionette; in the last two sentences of this soliloquy, Craig pretends that the marionette who is speaking here is precisely that Burmese tiger, and that it is talking about its tail. But a tiger marionette can scarcely be said to have two hands and two feet, and Craig's very reluctance (which must not be mentioned), the question mark after the word tail, and his use of Italian words (certain topics always are easier to tackle in a foreign language...) make it quite clear that he actually had another unruly member in mind. Throughout his life, Craig remained very much something of a prudish Victorian... which makes it all the more difficult to acknowledge the symbolic and religious value of phallism in his work and thought.

${ }^{2}$ Undated Craig's note on the back of first cover page.

${ }^{3}$ Also in an unpublished letter from Craig to Cooper, 23 April 2010.

\section{References}

BABLET, Denis. Edward Gordon Craig. Translation: Daphne Woodward. London: Heinemann, 1966.

CRAIG, Edward Gordon (Britannicus). Art and the Nation. The Mask, v. 5, n. 1, p. 6-15, 1912.

CRAIG, Edward Gordon. Books and Theatres. London/Toronto: J.M. Dent \& Sons Ltd., 1925.

CRAIG, Edward Gordon. Catalogue of Etchings Being Designs for Motions. Florence: Stabilimento Aldino, 1908.

CRAIG, Edward Gordon. An Easy Book on the Theatre. Unpublished manuscript. Paris: Bibliothèque Nationale de France, 1922. (Craig Collection, EGC-Ms-A-57.)

CRAIG, Edward Gordon. [Memoirs]. Unpublished manuscript. Paris: Bibliothèque Nationale de France, 1950. (Craig Collection, EGC-Ms-B-34.)

CRAIG, Edward Gordon; CHAMBERLAIN, Franc (Ed.). On the Art of the Theatre. London/New York: Routledge, 2009.

CRAIG, Edward Gordon; CHÉNETIER-ALEV, Marion; DUVILLIER, Marc; PLASSARD, Didier (Ed.). The Drama for Fools. Charleville-Mézières/Montpellier: Institut International de la Marionnette/L'Entretemps, 2012.

CRAIG, Edward Gordon. The Theatre - Advancing. Boston: Little, Brown, and Company, 1919.

CRAIG, Edward Gordon. Uber-Marions. Unpublished manuscript in two volumes. Paris: Bibliothèque Nationale de France, 1905-1906. (Craig Collection, EGC-Ms-A-23.)

CRAIG, Edward Gordon. Undated Manuscript Annotations. In: SKRINE, Francis Henry. Bahaism: the religion of brotherhood and its place in the evolution of creeds. London/Paris: 
Longmans, Green and Co./Bibliothèque Nationale de France, 1912. (Craig Collection, 16-EGC-1942.)

CRAIG, Edward. Gordon Craig: the story of his life. New York: Limelight Editions, 1985. CRITON, Pascale. Liner-notes. Ivan Wyschnegradsky, La Journée de l'Existence. Sound recording. [S.1.]: Shiiin, 2009.

DIPIETRO, Cary. Shakespeare and Modernism. Cambridge: Cambridge University Press, 2006.

EYNAT-CONFINO, Irène. Beyond the Mask: Gordon Craig, movement, and the actor. Carbondale/Edwardsville: Southern Illinois University Press, 1987.

FLANAGAN, Hallie. Shifting Scenes of the Modern European Theatre. New York: Coward-McCann, 1928.

FRANKLIN, Colin. Fond of Printing: Gordon Craig as typographer and illustrator. London: Hurtwood Publications, 1980.

FREIXE, Guy. Les Utopies du Masque sur les Scènes Européennes du XXe Siècle. Montpellier: L'Entretemps, 2010.

HARPER, Margaret Mills. Yeats and the Occult. In: HOWES, Marjorie; KELLY, John (Ed.). The Cambridge Companion to W. B. Yeats. Cambridge: Cambridge University Press, 2006.

INNES, Christopher. Edward Gordon Craig: a vision of theatre. London/New York: Routledge, 1998.

KUZMANOVIĆ, N. Natasha. John Paul Cooper: designer and craftsman of the arts and crafts movement. Stroud: Sutton Publishing, [1999].

LE BOEUF, Patrick. Edward Gordon Craig and the Tempest. In: BROWN, Eric C.; RIVIER, Estelle (Ed.). Shakespeare in Performance. Newcastle upon Tyne: Cambridge Scholars Publishing, 2013. P. 48-68; P. 235-238.

LE BOEUF, Patrick. El Dios Escondido de Craig: aspectos espirituales de la estética craigiana. In: HERRERA, Aurora (Ed.). Edward Gordon Craig: el espacio como espectáculo. Madrid: La Casa Encendida, 2009. P. 12-35.

LE BOEUF, Patrick. The Über-Marionette: facts and (felicitous) misunderstandings. In: GUIDICELLI, Carole (Ed.). Über-Marionettes and Mannequins: Craig, Kantor and their contemporary legacies. Charleville-Mézières/Lavérune: Institut International de la Marionnette/L'Entretemps, 2013. P. 54-62.

LEWIS, Pericles. Modernism and Religion. In: LEVENSON, Michael (Ed.). The Cambridge Companion to Modernism. 2. ed. Cambridge: Cambridge University Press, 2011.

LOSCO-LENA, Mireille. La Scène Symboliste (1890-1896): pour un théâtre spectral. Grenoble: ELLUG, 2010. 
MAGNIN, Charles. Histoire des Marionnettes en Europe: depuis l'antiquité jusqu'à nos jours. Paris: Michel-Lévy Frères, 1852.

MANTZIUS, Karl. A History of Theatrical Art in Ancient and Modern Times. I The Earliest Times. Translation: Louise von Cossel. London: Duckworth and Co., 1903.

PASQUIER, Pierre. L'Infini qui Naît au Creux de la Paume, ou, Edward Gordon Craig et William Blake. Revue d'Histoire du Théâtre, v. 36, n. 3, p. 227-246, 1984.

ROOD, Arnold. After the Practice the Theory: Gordon Craig and movement. Theatre Research, v. 11, n. 2-3, p. 81-101, 1971.

SERRURIER, Lindor. De Wajang Poerwå: eene ethnologische studie. Leiden: E.J. Brill, 1896.

SHEREN, Paul. Gordon Craig's Only American Production. The Princeton University Library Chronicle, v. 29, n. 3, p. 163-192, 1968.

SIMONSON, Lee. The Case of Gordon Craig. Theater Guild Magazine, v. 1, p. 19-20, 1931.

SIMONSON, Lee. The Stage is Set. New York: Harcourt, Brace, and C', 1932.

SPIECKERMANN, Thomas. The World lacks and needs a Belief: Untersuchungen zur metaphysischen Ästhetik der Theaterprojekte Edward Gordon Craigs von 1905 bis 1918. Trier: WVT Wissenschaftlicher Verlag Trier, 1998.

TAXIDOU, Olga. The Mask: a periodical performance by Edward Gordon Craig. Amsterdam: Harwood Academic Publishers, 1998.

Patrick Le Boeuf is a library curator at the National Library of France. From 2006 to 2009, he was in charge of the Edward Gordon Craig Collection in the Performing Arts Department of that institution.

E-mail: patrick.le-boeuf@bnf.fr

This unpublished text, reviewed by Ananyr Porto Fajardo, is also published in Portuguese in this issue. 